\title{
STUDI KASUS PEMENUHAN KEBUTUHAN NUTRISI PADA \\ PASIEN PPOK DI RUMAH SAKIT TINGKAT II PUTRI HIJAU MEDAN TAHUN 2017
}

\author{
Case Study of the Fulfillment of Airway Clearance in Pulmonary TB Patients \\ at the Putri Hijau Hospital II Medan in 2017
}

\author{
Lermiana Purba ${ }^{1}$, Deni Susyanti ${ }^{2}$, Lilis Savanna Siahaan ${ }^{3}$ \\ ${ }^{1,2}$ Dosen Tetap Yayasan Akper Kesdam I/BB Medan \\ ${ }^{3}$ Mahasiswa Akper Kesdam I/BB Medan \\ E-mail: deni_susyanti@yahoo.co.id
}

\begin{abstract}
Abstrak
Latar belakang. Penyakit Paru Obstruksi Kronik (PPOK) merupakan penyakit kronis yang ditandai dengan batuk produktif dan dispnea dan terjadinya obstruksi saluran nafas sekalipun penyakit ini bersifat kronis dan merupakan gabungan dari emfisema, bronkiolitis kronik maupun asma. Salah satu tanda dan gejala yang sering terjadi pasien Penyakit Paru Obstruksi Kronis adalah terjadinya penurunan berat badan. Desain penelitian ini merupakan penelitian deskriptif dengan 2 pasien Penyakit Paru Obstruksi Kronis di Rumah Sakit Tk II Putri Hijau Medan. Adapun hasil yang didapatkan dari kedua responden pasien Penyakit Paru Obstruksi Kronis yaitu pemenuhan kebutuhan nutrisi kedua pasien terpenuhi namun wakt nya yang berbeda dimana pasien I dalam pemenuhan kebutuhan nutrisi dapat terpenuhi di hari ke 2 perawatan, sedangkan pasien II pemenuhan kebutuhan nutrisi dapat terpenuhi pada hari ke 3 , hal ini dikarenakan perbedaan usia dari kedua responden. Dari hasil diatas peneliti menyimpulkan bahwa pemenuhan kebutuhan nutrisi pasien Penyakit Paru Obstruksi Kronis memiliki perbedaan dalam pemenuhan kebutuhan nutrisi dikarenakan adanya perbedaan usia. Adapun saran dari hasil diatas terutama kepada responden untuk selalu memperhatikan program pola pemenuhan kebutuhan nutrisi pada pasien Penyakit Paru Obstruksi Kronis.
\end{abstract}

Kata kunci : Nutrisi, Penyakit Paru Obstruksi Kronis, Kronis.

\begin{abstract}
Background of Chronic Pulmonary Obstruction Disease (COPD) is identified by productive coughing, dyspnea, and obstruction in the respiratory tract. It is the combination of emphysema, chronic bronchiolitis, and asthma. One of the symptom of COPD is the decrease in bodyweight. The research used descriptive method with 2 COPD patients at Putri Hijau Level II Hospital Medan. The result of the analysis on the 2 patients showed that their need for nutrition was fulfilled but in different time, the need for nutrition in patient 1 was fulfilled in the $2^{\text {nd }}$ day while in patient 2 it was fulfilled in the $3^{\text {nd }}$ day due to the difference in their age. The conclusion was that the need for nutrition in COPD patients was different because of the difference in age. It is recommended that COPD patients always pay attention to the program in fulfilling their need for nutrition.
\end{abstract}

Keywords: Nutrition, Chronic Obstruction Pulmonary Desease, Chronic

\section{PENDAHULUAN}

Penyakit Paru Obstruktif Kronik merupakan suatu istilah yang sering di gunakan untuk sekelompok penyakit paruparu yang berlangsung lama dan ditandai oleh peningkatan resistensi terhadap aliran udara sebagai gambaran patofisiologi (Padila, 2012). Obstruksi jalan napas yang menyebabkan reduksi aliran udara beragam tergantung pada penyakit. Pada bronchitis kronik dan bronkiolitis, penumpukan lendir dan sekresi yang sangat banyak penyumbat jalan napas. Pada emfisema, obstruksi pada pertukaran oksigen dan karbon di oksida terjadi di akibat kerusakan dinding alveoli yang disebabkan oleh overekstensi ruang udara dalam paru.

Pada asma, jalan bronkhial menyempit dan membatasi jumlah udara yang mengalir kedalam paru-paru. Protokol pengobatan tertentu digunakan dalam semua kelainan ini, meskipun patofisiologi dari masing-masing kelainan ini membutuhkan pendekatan spesifik. Sebagian besar prevalensi kasus, PPOK adalah perilaku merokok, merokok adalah faktor resiko utama 
yang menyebabkan terjadinya PPOK. Faktor resiko lain juga dapat menyebabkan terjadinya PPOK adalah polusi udara, perokok pasif,riwayat infeksi saluran pernafasan,dan keturunan (Smeltzer \& Bare, 2012).

Laporan data berdasarkan WHO terdapat 600 juta orang menderita PPOK di dunia dengan 65 juta orang menderita PPOK derajat sedang hingga berat. Lebih dari 3 juta orang meninggal karena PPOK pada tahun 2005 , yang arti nya setara dengan $5 \%$ dari semua kematian secara global (WHO, 2015 dalam Kemenkes RI, 2012). Hasil laporan data penyakit tidak menular oleh Sistem Informasi Rumah Sakit (SIRS) tahun 2011, menunjukkan PPOK termasuk dalam 10 besar penyebab kematian penyakit tidak menular rawat inap di rumah sakit Indonesia sebesar 6,74\% ( Kemenkes RI, 2012 dalam Riskesdas 2013)

Penyakit Paru Obstruktif Kronik (PPOK) merupakan salah satu dari kelompok penyakit tidak menular yang telah menjadi masalah kesehatan masyarakat Indonesia. Prevalensi PPOK berdasarkan wawancara di Indonesia adalah 3,7 persen. Prevalensi PPOK lebih tinggi pada laki-laki dibandingkan perempuan (Riskesdas, 2013).

Menurut data Riskesdas 2013 menunjukkan bahwa di Sumatera Utara jumlah penderita PPOK mencapai 3,6 persen yang cenderung dialami oleh masyarakat dengan pendidikan rendah.

Dari sudut pandang epidemiologi, laki-laki lebih beresiko terkena PPOK di bandingkan wanita karena kebiasaan merokok. Gambaran khas PPOK adalah adanya obstruksi saluran napas yang sangat bervariasi mulai dari tanpa gejala, gejala ringan, hingga berat, sehingga menyebabkan keterbatasan dalam aktivitas sehari-hari penderita yang bergantung pada beratnya sesak, semakin berat derajat sesak napas, maka semakin sulit penderita melakukan aktivitas (Zamzam, 2012).

Kualitas hidup dapat sangat terganggu pada pasien PPOK dengan semakin meningkatnya derajat penyakit yang dideritanya. Penelitian tersebut mendapatkan hasil penelitian yang menunjukkan pasien dengan PPOK derajat ringan dan sedang memiliki kualitas hidup yang baik, sedangkan pasien dengan dejarat PPOK berat dan sangat berat memiliki kualitas hidup yang buruk (Zamzam, 2012).

Menurut hasil penelitian Abdul Ghofar tahun 2014, menyimpulkan hasil penelitian bahwa ada perbandingan yang signifikan antara orang yang merokok dengan yang tidak merokok. Semakin tinggi tingkat merokok seseorang maka semakin tinggi pula seseorang tersebut terkena PPOK dari pada yang tidak merokok.

Adapula hasil penelitian lain Dani tahun 2012 menyimpulkan bahwa karateristik penderita PPOK tahun 2012 lebih banyak pada usia 61-70 tahun, laki-laki dengan adanya riwayat merokok, dan paling sering datang dengan keluhan sesak napas.

Hasil penelitian Fajrin (2015) tentang status nutrisi pada pasien PPOK bahwa 30,2\% penderita PPOK memiliki status gizi yang buruk. Hal ini dapat terjadi karena bertambahnya kebutuhan energi akibat kerja muskulus respirasi yang meningkat karena hipoksemia menyebabkan hipermetabolisme, sehingga sering mengalami penurunan berat badan.

Hasil penelitian yang dilakukan oleh (Chhabra, 2012) menunjukkan bahwa merokok pada pasien dengan PPOK menunjukkan penurunan berat badan setelah disesuaikan menurut gender, status ekonomi di populasi India.

Menurut penelitian Suryadinata (2017) menunjukkan bahwa dari 55 perokok aktif sebanyak 31 orang masuk ke dalam kategori IMT underweight $(<18,5)$ sehingga dapat disimpulkan bahwa sebagian besar perokok aktif kekurangan asupan nutrisi.

Hermi, (2012) menunjukkan bahwa jumlah karbohidrat pada diet TKTP I 400 gram, protein 100 gram, lemak 72,7 gram, kalori 2500 kkal dan untuk diet TKTP II jumlah karbohidrat 415 gram, protein 120 gram, lemak 100 gram, dan kalori 3000 kkal.

Nieniek, (2015) mengatakan hasil penelitiannya bahwa posisi high fowler dan orthopneic dapat meningkatkan nilai arus puncak ekspirasi. Fungsi ventilasi paru klien terlihat lebih baik dengan posisi orthopneic daripada posisi high fowler. Berdasarkan hasil temuan ini, direkomendasikan agar memberikan posisi orthopneic kepada klien PPOK dengan dispnea untuk meningkatkan fungsi ventilasi paru. 
Batuk efektif yang baik dan benar akan dapat mempercepat pengeluaran dahak pada pasien dengan gangguan saluran pernafasan penyakit paru obstruktif kronik (PPOK) (Nugroho, 2011).

Berdasarkan uraian diatas, PPOK merupakan penyakit penyebab kematian. Karena semakin banyak penderita PPOK di Indonesia terutama di Rumah Sakit Putri Hijau TK II Medan terhitung mulai dari Januari 2017- Oktober 2017 ada sebanyak 51 jiwa, maka penulis tertarik untuk melakukan studi kasus Pemenuhan Kebutuhan Nutrisi Pada Pasien PPOK Di Rumah Sakit TK II Putri Hijau Medan Tahun 2018.

\section{METODE}

Penelitian ini merupakan penelitian deskriptif dengan rancangan studi kasus pemenuhan kebutuhan nutrisi pada pasien PPOK dengan menggunakan pendekatan proses keperawatan yang dilakukan peneliti. Subyek penelitian yang digunakana adalah 2 pasien dengan 1 kasus dengan masalah keperawatan yang sama. Studi kasus berjudul Pemenuhan Kebutuhan Nutrisi Pada Pasien PPOK dengan kriteria inklusi: bersedia menjadi subjek penelitian, pasien PPOK, Usia (40 Tahun ke atas), dengan pemenuhan kebutuhan nutrisi. Kriteria eksklusi: pasien menolak penelitian, memiliki komplikasi yaitu insufisiensi pernapasan, gagal napas, pneumonia, atelektasis, pneumothoraks. Fokus studi dalam penelitian ini yaitu pemenuhan kebutuhan nutrisi pada pasien PPOK dengan dua pasien dalam kasus yang sama. Laporan ini penulis membatasi pada Asuhan Keperawatan Medikal Bedah dengan Gangguan Sistem Pernapasan PPOK di Rumah Sakit Putri Hijau TK II Medan lama sejak pasien pertama kali masuk rumah sakit sampai pulang dan atau yang dirawat minimal 4 hari. Penelitian akan dilakukan pada bulan Mei 2017 dengan Juli 2017.

Alat atau instrument pengumpulan data dalam wawancara menggunakan format pengkajian asuhan keperawatan medikal bedah sedangkan dalam observasi menggunakan alat-alat seperti tensimeter, stetoskop, dan timbangan. Metode Pengumpulan data dalam karya tulis studi kasus ini adalah dengan menggunakan instrument Biofisiologis, Observasi, Wawancara, Kuesioner, dan Skala penilaian.

\section{HASIL \\ Gambaran Umum Rumah Sakit}

Rumkit Tk II Putri Hijau Kesdam I/BB beralamat di Jl. Putri Hijau No. 17 Kel. Kesawan Kecamatan Medan Barat Kodya Medan Sumatera Utara.

\section{Struktur Organisasi Rumkit Tk II Putri Hijau}

Struktur organisasi Rumkit Tk II Putri Hijau berdasarkan pada Peraturan Kepala Staf TNI Angkatan Darat Nomor Perkasad/25/XII/2007 tanggal 31 Desember 2007 tentang Organisasi dan Tugas Kesehatan Daerah Militer (Kesdam) termasuk Rumah Sakit Tk II Putri Hijau.

\section{Jenis Pelayanan}

Dalam operasionalnya Rumkit Tk II Putri Hijau Kesdam I/BB memiliki fasilitas pelayanan:

a) Rawat jalan/poliklinik,

b) Rawat Inap

c) Sarana Penunjang

\section{Hasil \\ Pengkajian}

a. Identitas dan Hasil Anamnesa

Pengkajian

a. Identitas dan hasil anamnesa

Tabel 4.1. identitas pasien dan hasil anamnesa

\begin{tabular}{|c|c|c|c|}
\hline No & $\begin{array}{l}\text { Identitas } \\
\text { pasien }\end{array}$ & Pasien I & Pasien II \\
\hline 1 & $\begin{array}{l}\text { Diagnosa } \\
\text { Medis }\end{array}$ & PPOK & PPOK \\
\hline 2 & Nama & Tn.S & Tn.L \\
\hline 3 & Umur & 56 tahun & 90 tahun \\
\hline 4 & $\begin{array}{l}\text { Jenis } \\
\text { kelamin }\end{array}$ & Laki-laki & Laki-laki \\
\hline 5 & Pendidikan & SMA & SMP \\
\hline 6 & Pekerjaan & Pensiunan TNI & $\begin{array}{l}\text { wirausah } \\
\text { a }\end{array}$ \\
\hline 7 & Status & Kawin & Kawin \\
\hline 8 & Agama & Islam & Protestan \\
\hline 9 & $\begin{array}{l}\text { Suku/ } \\
\text { bangsa }\end{array}$ & Jawa/ Indonesia & $\begin{array}{l}\text { Batak/In } \\
\text { donesia }\end{array}$ \\
\hline 10 & Bahasa & Indonesia & $\begin{array}{l}\text { Indonesi } \\
\text { a }\end{array}$ \\
\hline 11 & Alamat & Pematang siantar & $\begin{array}{l}\text { Sei } \\
\text { bingai }\end{array}$ \\
\hline
\end{tabular}




\begin{tabular}{|c|c|c|c|}
\hline 12 & $\begin{array}{l}\text { Ditanggung } \\
\text { oleh }\end{array}$ & BPJS & BPJS \\
\hline 13 & $\begin{array}{l}\text { Tanggal } \\
\text { dan jam } \\
\text { masuk } \\
\text { rumah sakit }\end{array}$ & $\begin{array}{l}10 \text { juli } 2018 \\
\text { pukul } 07.00\end{array}$ & $\begin{array}{l}23 \text { juli } \\
2018 \\
\text { pukul } \\
08.00\end{array}$ \\
\hline 14 & $\begin{array}{l}\text { Tanggal } \\
\text { dan jam } \\
\text { masuk } \\
\text { ruangan }\end{array}$ & $\begin{array}{l}10 \text { juli } 2018 \\
\text { pukul } 08.00\end{array}$ & $\begin{array}{l}23 \text { juli } \\
2018 \\
\text { pukul } \\
09.00\end{array}$ \\
\hline 15 & $\begin{array}{l}\text { Tanggal } \\
\text { dan jam } \\
\text { pengkajian }\end{array}$ & $\begin{array}{l}10 \text { juli } 2018 \\
\text { pukul } 09.00\end{array}$ & $\begin{array}{l}24 \text { juli } \\
2018 \\
\text { pukul } \\
07.00\end{array}$ \\
\hline
\end{tabular}

Berdasarkan tabel 4.1 didapatkan dari 2 pasien mempunyai diagnosa medis yang sama yaitu PPOK. Pada pasien I berumur 56 tahun sedangkan pada pasien II berumur 90 tahun.

b. Keluhan utama dan riwayat sakit

Tabel 4.2 keluhan utama dan riwayat sakit

\begin{tabular}{|c|c|c|c|}
\hline No & Data fokus & Pasien I & Pasien II \\
\hline 1 & $\begin{array}{l}\text { Alasan } \\
\text { masuk RS }\end{array}$ & $\begin{array}{l}\text { Sesak } \\
\text { napas, } \\
\text { nyeri pada } \\
\text { dada, } \\
\text { batuk. }\end{array}$ & $\begin{array}{l}\text { Sesak, } \\
\text { batuk } \\
\text { berdahak, } \\
\text { mual }\end{array}$ \\
\hline 2 & $\begin{array}{l}\text { Keluhan } \\
\text { utama saat } \\
\text { masuk } \\
\text { Rumah Sakit }\end{array}$ & $\begin{array}{l}\text { Sesak } \\
\text { napas, } \\
\text { batuk, } \\
\text { nyeri dada. }\end{array}$ & $\begin{array}{l}\text { Sesak } \\
\text { napas, } \\
\text { batuk } \\
\text { berdahak, } \\
\text { dan mual. }\end{array}$ \\
\hline 3 & $\begin{array}{l}\text { Keluhan } \\
\text { utama saat } \\
\text { pengkajian }\end{array}$ & $\begin{array}{l}\text { Sesak } \\
\text { napas, } \\
\text { batuk, } \\
\text { nyeri dada. }\end{array}$ & $\begin{array}{l}\text { Sesak } \\
\text { napas, } \\
\text { batuk } \\
\text { berdahak, } \\
\text { dan mual. }\end{array}$ \\
\hline 4 & $\begin{array}{l}\text { Riwayat } \\
\text { penyakit } \\
\text { sekarang }\end{array}$ & $\begin{array}{l}\text { Pada } \\
\text { tanggal } 10 \\
\text { juli } 2018 \\
\text { sekitar } \\
\text { pukul } \\
07.00 \text { wib, } \\
\text { pasien } \\
\text { dibawa ke } \\
\text { rumah sakit } \\
\text { Putri Hijau } \\
\text { dengan } \\
\text { keluhan } \\
\text { sesak } \\
\text { napas, } \\
\text { nyeri dada, } \\
\text { batuk,. } \\
\text { Pukul } \\
\text { 08.00 wib }\end{array}$ & $\begin{array}{l}\text { Pada } \\
\text { tanggal } 23 \\
\text { juli } 2018 \\
\text { sekitar } \\
\text { pukul } \\
08.00 \text { wib, } \\
\text { pasien } \\
\text { dibawa ke } \\
\text { rumah sakit } \\
\text { Putri Hijau } \\
\text { dengan } \\
\text { keluhan } \\
\text { sesak } \\
\text { napas, } \\
\text { batuk } \\
\text { berdahak } \\
\text { serta mual. } \\
\text { Pukul }\end{array}$ \\
\hline
\end{tabular}

\begin{tabular}{|c|c|}
\hline $\begin{array}{l}\text { dibawa ke } \\
\text { ruangan } \\
\text { perawatan. }\end{array}$ & $\begin{array}{l}09.00 \text { wib } \\
\text { klien } \\
\text { dibawa ke } \\
\text { ruangan } \\
\text { perawatan. } \\
\text { PPOK }\end{array}$ \\
\hline Tidak ada & Tidak ada \\
\hline $\begin{array}{l}\text { Riwayat } \\
\text { merokok }\end{array}$ & $\begin{array}{l}\text { Riwayat } \\
\text { merokok }\end{array}$ \\
\hline
\end{tabular}

Berdasarkan tabel 4.2 didapatkan bahwa pasien I dan pasien II memiliki alasan masuk rumah sakit karena sesak napas, dan batuk. Pada pasien I dan pasien II sama - sama memiliki keluhan saat awal masuk rumah sakit yaitu sesak napas. Keluhan utama saat pengkajian pada pasien I yakni sesak napas dan batuk. Sedangkan pada pasien II mengalami sesak napas, batuk berdahak, dan mual. Pada riwayat penyakit sekarang pada pasien I dan pasien II sama - sama dilakukan trombolitik. Pasien I dan pasien II sama sama memiliki riwayat penyakit dahulu PPOK. Pasien I dan pasien II memiliki kebiasaan yang terdahulu yaitu merokok.

\section{c. Hasil Observasi (Pemeriksaan Fisik)}

Tabel 4.3 hasil Observasi (Pemeriksaan Fisik)

\begin{tabular}{|c|c|c|c|c|}
\hline $\mathrm{N}$ & Observas & Pasien I & Pasien I & \\
\hline 1 & $\begin{array}{l}\text { Keadaan } \\
\text { umum }\end{array}$ & $\begin{array}{l}\text { a) Keadaa } \\
\mathrm{n} \\
\text { umum } \\
\text { klien } \\
\text { tampak } \\
\text { lemah } \\
\text { b) Kesada } \\
\text { ran } \\
\text { compo } \\
\text { s } \\
\text { mentis } \\
\text { c) GCS } \\
15 \\
\text { d) Terpas } \\
\text { ang } \\
\text { Infus } \\
\text { Rl } 20 \\
\text { gtt/i } \\
\text { e) Terpas } \\
\text { ang } \\
\text { oksige } \\
\text { n nasal } \\
\text { kanul }\end{array}$ & $\begin{array}{l}\text { c) } \\
\text { d) }\end{array}$ & $\begin{array}{l}\text { Keadaan } \\
\text { umum } \\
\text { klien } \\
\text { tampak } \\
\text { lemah } \\
\text { Kesadara } \\
\text { n } \\
\text { compos } \\
\text { mentis } \\
\text { GCS 15 } \\
\text { Terpasan } \\
\text { g infus } \\
\text { Rl 20 } \\
\text { gtt/i } \\
\text { Terpasan } \\
\text { g } \\
\text { oksigen } \\
\text { nasal } \\
\text { kanul } \\
\text { 5L/i }\end{array}$ \\
\hline
\end{tabular}




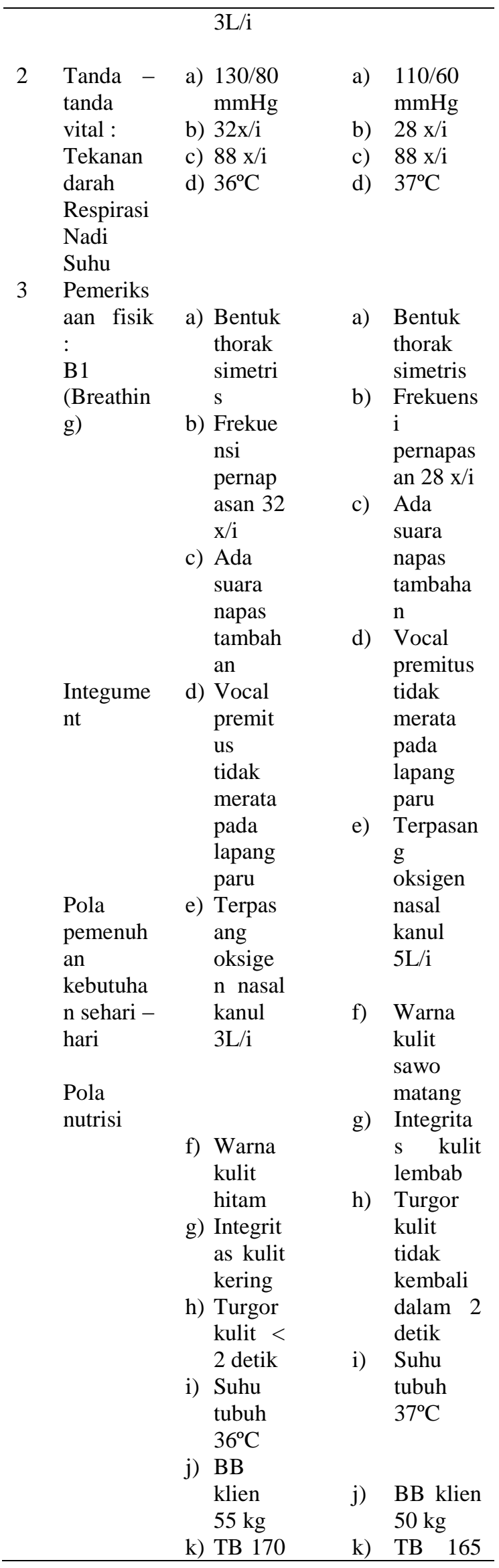

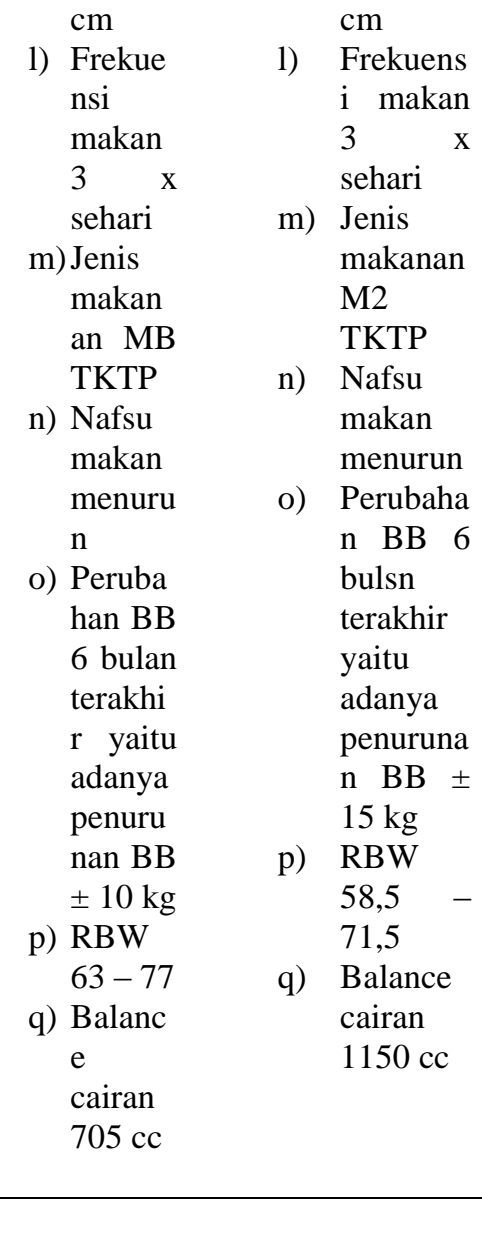

Berdasarkan tabel 4.3 dapat disimpulkan bahwa hasil observasi pasien I dan pasien II ditemukan bahwa pada pasien I ditemukan keadaan umum pasien lemah, kesadaran composmentis, GCS 15, terpasang oksigen $3 \mathrm{~L} / \mathrm{i}$, terpasang infus $20 \mathrm{gtt} / \mathrm{i}$, tanda- tanda vital tekanan darah 130/80 mmHg, P $88 \mathrm{x} / \mathrm{i}$, $\mathrm{RR} 32 \mathrm{x} / \mathrm{i}, \mathrm{T} 36^{\circ} \mathrm{C}$. bentuk thorak simetris, frekuensi pernapasan $32 \mathrm{x} / \mathrm{i}$, ada suara napas tambahan, vocal premitus tidak merata pada lapang paru, warna kulit hitam, integritas kulit kering, turgor kulit < 2 detik, BB klien $55 \mathrm{~kg}$, TB $170 \mathrm{~cm}$, frekuensi makan $3 \mathrm{x}$ sehari, jenis makanan MB TKTP, nafsu makan menurun, perubahan BB 6 bulan terakhir yaitu adanya penurunan $\mathrm{BB} \pm 10 \mathrm{~kg}$, RBW $63-77$, balance cairan $705 \mathrm{cc}$. Sedangkan pada pasien II keadaan umum pasien lemah, kesadaran klien compos mentis, GCS 15, terpasang oksigen 5L/i, terpasang infus $20 \mathrm{gtt} / \mathrm{i}$, tanda tanda vital, tekanan darah 110/60 mmHg, P 88 $\mathrm{x} / \mathrm{i}$, RR $28 \mathrm{x} / \mathrm{i}, \mathrm{T} 37^{\circ} \mathrm{C}$, bentuk thorak simetris, vocal premitus tidak merata pada lapang paru, frekuensi pernapasan $28 \mathrm{x} / \mathrm{i}$, ada bunyi nafas 
tambahan, warna kulit sawo matang, integritas kulit lembab, turgor kulit tidak kembali dalam 2 detik, BB $50 \mathrm{~kg}$, TB $165 \mathrm{~cm}$, RBW 58,5 71,5, frekuensi makan $3 \mathrm{x}$ sehari, jenis makanan M2 TKTP, nafsu makan menurun, perubahan BB 6 bulan terakhir yaitu adanya penurunan $\mathrm{BB} \pm 15 \mathrm{~kg}$, balance cairan 1150 cc.

d. Pemeriksaan diagnostik

Tabel 4.4 pemeriksaan diagnostic

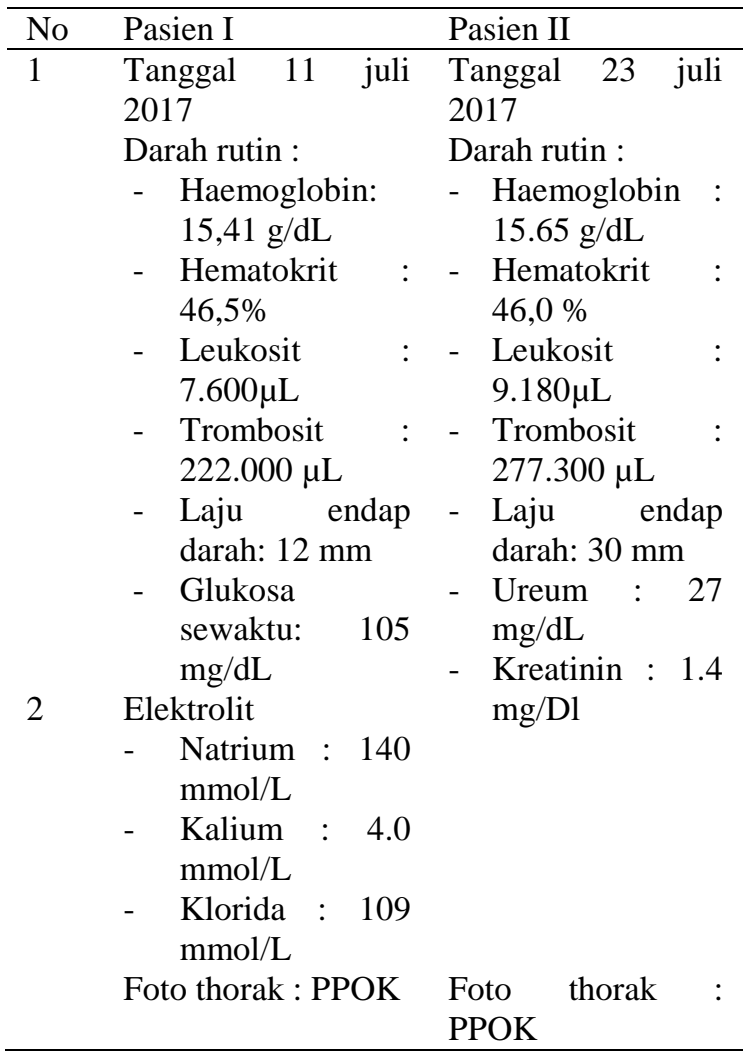

Berdasarkan tabel 4.4 dari hasil pemeriksaan diagnostik dapat disimpulkan bahwa dari pasien I dan pasien II dilakukan pemeriksaan dalam laju endap darah. Pada pasien I dilakukan pemeriksaan glukosa sewaktu, natrium, kalium, dan klorida. Sedangkan pada pasien II dilakukan pemeriksaan ureum, kreatinin. Pada Pasien I dan II dilakukan pemeriksaan rontgen yaitu foto thorax dan positif PPOK.

\section{e. Analisa data}

Dari hasil analisa data dapat disimpulkan bahwa pasien I mengalami gangguan pemenuhan kebutuhan nutrisi kurang dari kebutuhan tubuh berhubungan dengan kehilangan nafsu makan sehingga terjadi penurunan energi ditandai dengan klien tidak nafsu makan, diet yang diberikan hanya habis $1 / 2$ porsi, klien tampak kurus, BB $55 \mathrm{~kg}$, pemberian $\mathrm{O} 23 \mathrm{~L} / \mathrm{i}$. sedangkan pada pasien II mengalami gangguan pemenuhan kebutuhan nutrisi kurang dari kebutuhan tubuh berhubungan dengan kehilangan nafsu makan sehingga terjadi penurunan energi ditandai dengan klien tampak mual, klien tampak tidak nafsu makan BB $50 \mathrm{~kg}$, diet yang diberikan hanya habis $1 / 2$ porsi, pemberian $\mathrm{O} 25 \mathrm{~L} / \mathrm{i}$.

\section{f. Diagnosa Keperawatan}

Dari kedua pasien didapatkan masalah gangguan pemenuhan kebutuhan nutrisi kurang dari kebutuhan tubuh berhubungan dengan kehilangan nafsu makan sehingga terjadi penurunan energi.

\section{g. Rencana Keperawatan}

Tabel 4.7. rencana keperawatan

$\frac{\text { Perencanaan dan rasional }}{\text { 1. kaji kebiasaan diet,masukan makanan saat }}$
ini,catat derajat kesulitan makan. Evaluasi berat badan dan ukuran tubuh. R/ pasien distress pernapasan akut sering anoreksia karena dispnea,produksi sputum dan obat 2. Auskultasi bunyi usus. R/ penurunan/hipoaktif usus menunjukkan penurunan motilitas gaster dan konstipasi(komplikasi umum) yang berhubungan dengan pembatasan pemasukan cairan

3. Berikan perawatan oral sering,buang secret,berikan wadah khusus untuk sekali pakai dan tisu. R/ Rasa tidak enak,bau dan penampilan adalah pencegahan utama terhadap nafsu makan dan dapat membuat mual dan muntah dengan peningkatan kesulitan nafas.

4. Dorong periode istirahat selama 1 jam sebelum dan sesudah makan. Berikan makan porsi kecil tapi sering. R/ Membantu menurunkan kelemahan selama waktu makan dam memberikan kesempatan untuk meningkatkan masukan kalori total.

5. Hindari makanan penghasil gas dan minuman karbonat. R/ Dapat menghasilkan distensi abdomen yang mengganggu nafas abdomen dan gerakan diafragma dan dapat meningkatkan dispnea. 


\begin{tabular}{l} 
6. Hindari makanan yang sangat panas dan \\
sangat dingin. R/ Suhu ekstrim dapat \\
mencetuskan/meningkatkan spasme batuk. \\
7. Timbang berat badan sesuai indikasi. R/ \\
Berguna untuk mementukan kebutuhan \\
kalori,menyusun tujuan berat badan,dan \\
evaluasi keadekuatan rencana nutrisi. \\
8. Konsul ahli gizi/nutrisi pendukung tim \\
untuk memberikan makanan yang mudah \\
dicerna,secara nutrisi seimbang,mis,nutrisi \\
tambahan oral/selang,nutrisi parenteral. R/ \\
Metode makan dan kebutuhan kalori \\
didasarkan pada situasi/kebutuhan individu \\
untuk memberikan nutrisi maksimal dengan \\
upaya minimal pasien/pengunaan energy \\
9. Kaji pemeriksaan laboratorium, \\
mis,albumin serum,transferin,profil asam \\
amino,besi,pemeriksaan keseimbangan \\
nitrogen,glukosa pemeriksaan fungsi \\
hati,elektrolit,berikan vitamin,/ mineral/ \\
elektrolit sesuai indikasi. R/ Mengevaluasi/ \\
mengatasi kekurangan dan mengawasi \\
keefektifan terapi nutrisi. \\
10. Berikan oksigen tambahan selama makan \\
sesuai indikasi. R/ Menurunkan dipsnea dan \\
meningkatkan energy untuk makan \\
meningkatkan masukan \\
\hline
\end{tabular}

Berdasarkan table diatas didapatkan dari kedua pasien memiliki rencana keperawatan yang sama sesuai dengan Doengoes, 2012 untuk pasien dengan diagnosa gangguan pemenuhan kebutuhan nutrisi kurang dari kebutuhan tubuh.

\section{h. Implementasi keperawatan}

Berdasarkan hasil implementasi yang dilakukan kepada kedua responden merupakan tindakan keseluruhan yang ada dilakukan pada pasien PPOK karena pemenuhan kebutuhan nutrisi pada pasien Pasien I dan Pasien II memerlukan asuhan keperawatan yang komprehensif, juga didapatkan dari kedua responden mempunyai tindakan keperawatan yang sama dengan rencana keperawatan di ruang teratai rumah sakit tk II putri hijau medan.

\section{i. Evaluasi}

Berdasarkan hasil evaluasi yang telah dilakukan, peneliti memiliki keterbatasan waktu untuk mengevaluasi dalam melakukan implementasi keperawatan. Dari hasil evaluasi tersebut diperoleh hasil yang berbeda dari kedua responden. Pada pasien I klien sudah mulai nafsu makan pada hari ke 2 dan pada hari ke 3 klien sudah tidak lagi menggunakan oksigen selama makan karena sesak sudah mulai berkurang. Sedangkan pada pasien II klien sudah nafsu makan pada hari ke 3 dan sesak sudah mulai berk

oksigen sudah berkuran _

\section{Pembahasan}

Setelah peneliti melakukan penelitian studi kasus pemenuhan kebutuhan nutrisi pada Tn.S dan Pada Tn.L dengan gangguan system pernapasan PPOK di Rumah Sakit TK II Putri Hijau Medan, selama 8 hari mulai dari tanggal 10 Juli 2017 sampai dengan 13 Juli 2017 dan 24 Juli 2017 sampai dengan 27 Juli 2017. Dalam hal ini pembahasan yang dimaksud adalah membandingkan antara tinjaun kasus dengan tinjauan pustaka yang disajikan untuk menjawab tujuan khusus dari penelitian. Dimana setiap temuan perbedaan diuraikan dengan konsep dan pembahasan disusun dengan tujuan khusus.

Peneliti melakukan penelitian terhadap dua pasien yang sama - sama memiliki penyakit PPOK di Rumah Sakit Tk II Putri Hijau Medan dengan lima tahap sesuai dengan proses keperawatan yang dikembangkan oleh American Nurse Association (ANA) yaitu pengkajian, diagnosa keperawatan, perencanaan, implementasi dan evaluasi. Asosiasi diagnosa keperawatan Amerika (NANDA) kemudian mengembangkan dan mengelompokkan diagnosa keperawatan serta membantu menciptakan pola komunikasi antar perawat dan dapat memberikan batasan antara diagnose keperawatan dengan diagnosa medis. Diagnosa keperawatan berfokus pada respon klien, sedangkan diagnosa medis berfokus pada proses penyakit.

Tujuan khusus tersebut meliputi menggali pengkajian keperawatan, menyusun perencanaan asuhan keperawatan, merumuskan diagnosa keperawatan, melakukan implementasi yang komprehensif, serta melakukan evaluasi keperawatan. Berikut adalah pembahasan yang disesuaikan dengan tujuan khusus dari penelitian tersebut. Tahap Pengkajian

Pada tahap pengkajian didapatkan dari kedua pasien mempunyai diagnosa medis 
yang sama yang didasarkan pada adanya pemeriksaan radiologi sehingga kedua pasien sama - sama memiliki diagnosa PPOK.

Kedua pasien memiliki keluhan yang berbeda walaupun memiliki diagnosa yang sama. Berdasarkan tabel 4.4 hasil pengkajian kedua pasien memiliki jenis kelamin laki laki dan berumur diatas 40 tahun yakni pasien I berumur 56 tahun dan pasien II berumur 90 tahun. Menurut eka (2015) faktor pemicu biologis terjadinya PPOK tidak hanya usia lebih diatas 40 tahun, tetapi pasien dengan usia 40 tahun keatas lebih beresiko tinggi untuk mengalami PPOK. Sehingga dapat dikatakan perbedaan umur kedua partisipan juga dapat mempengaruhi tingkat kesembuhan.

Berdasarkan hasil pengkajian kedua partisipan memiliki jenis kelamin yang sama yakni laki - laki, menurut Zamzam (2012) dari sudut pandang epidemiologi laki - laki lebih beresiko terkena PPOK dibandingkan wanita karena kebiasaan merokok. Gambaran khas PPOK adalah adanya obstruksi saluran napas yang sangat bervariasi mulai dari tanpa gejala, gejala ringan, hingga berat, sehingga menyebabkan keterbatasan dalam aktivitas sehari-hari.

Pada kedua pasien memiliki riwayat perokok yang sudah lama. Menurut Abdul (2014) menyatakan bahwa perbandingan antara orang yang tidak merokok dan orang yang merokok, semakin tinggi tingkat merokok seseorang maka semakin tinggi pula seseorang tersebut terkena PPOK daripada yang tidak merokok.

Pada pasien I (Tn.S ) klien tidak mengalami mual sedangkan pada pasien II (Tn.L) mengalami mual. Mual yang dirasakan oleh Tn.L disebabkan oleh efek katabolisme yaitu dengan melihat status gizi, jika asupan kalori klien berkurang, maka tubuh akan memecah protein yang terdapat dalam otototot pernapasan yang berdampak pada menurunnya nafsu makan klien seperti mual dan muntah ( Enderina, 2016). Pada Tn.S tidak terjadi mual karena asupan kalori klien cukup daan klien tidak banyak melakukan aktivitas yang memicu terjadinya mual.
Diagnosa keperawatan

Pada kedua pasien yaitu pasien I dan Pasien II memiliki diagnose medis serta diagnosa keperawatan yang sama yaitu PPOK dengan diagnosa keperawatan gangguan pemenuhan kebutuhan nutrisi. Dimana data yang digunakan dalam menegakkan diagnosa keperawatan lebih difokuskan pada pemeriksaan dan pola nutrisi kedua responden, dan didapatkan hasil pada pasien I dan pasien II mempunyai masalah keperawatan yang sama yaitu gangguan pemenuhan kebutuhan nutrisi berhubungan dengan kehilangan nafsu makan,serta penurunan energy yang ditandai dengan keluhan tidak nafsu makan, terpasang infuse Rl 20 gtt/i, serta penurunan berat badan pada kedua klien.

Menurut Fajrin (2015) terjadinya status nutrisi yang buruk pada pasien PPOK karena bertambahnya kebutuhan energy akibat kerja muskulus respirasi yang meningkat karena hipoksemia menyebabkan hipermetabolisme, sehingga sering mengalami penurunan berat badan. Pada kedua klien mengalami perubahan nutrisi selama pasien dalam perawatan di rumah sakit. Hal inilah yang menyamakan pada teori bahwa penyakit PPOK akan mengalami masalah keperawatan perubahan nutrisi.

\section{Intervensi Keperawatan}

Dari table intervensi didapatkan dari kedua pasien mempunyai rencana tindakan keperawatan yang sama.

Dalam tahap perencanaan tindakan pada pasien, penulis tidak menemukan kesulitan karena keluarga dapat diajak bekerja sama dengan baik dalam menemukan rencana keperawatan dan mau menerima rencana tindakan keperawatan yang akan dilaksanakan terhadap pasien, agar tercapainya tujuan keperawatan klien.

Dalam hal ini penulis membuat rencana keperawatan sekaligus menentukan pendekatan yang digunakan untuk mencegah masalah yang mengakibatkan klien serta keluarga dengan berpedoman pada tinjauan teoritis saat melakukan asuhan keperawatan.

Adapun rencana keperawatan yang dilakukan pada Pasien I dan Pasien II: Gangguan pemenuhan kebutuhan nutrisi, intervensi yang diberikan yaitu: 
1) Kaji kebiasaan diet, masukan makanan saat ini, catat derajat kesulitan makan. Tujuannya: pasien distress pernapasan akut sering anoreksia karena dispnea.

2) Auskultasi bunyi usus. Tujuannya : penurunan/ hipoaktif usus menunjukkan penurunan motilitas gaster dan konstipasi

3) Berikan perawatan oral sering buang sekret, berikan wadah khusus untuk sekali pakai tisu. Tujuannya : rasa tidak enak, bau, dan penampilan adalah pencegahan utama terhadap nafsu makan dan dapat membuat mual muntah dengan peningkatan kesulitan nafas.

4) Dorong periode istirahat selama 1 jam sebelum dan sesudah makan. Tujuannya : membantu menurunkan kelemahan selama waktu makan dan memberikan kesempatan untuk meningkatkan masukan kalori total

5) Hindari makanan penghasil gas dan minuman berkarbonat. Tujuannya : dapat menghasilkan distensi abdomen yang mengganggu nafas abdomen dan gerakan diafragma dan dapat meningkatkan dispnea.

6) Hindari makanan yang sangat panas dan sangat dingin. Tujuannya: suhu ekstrim dapat mencetuskan/ meningkatkan spasme batuk.

7) Timbang berat badan sesuai indikasi. Tujuannya: berguna untuk menentukan kebutuhan kalori, menyusun tujuan berat badan, dan evaluasi keadekuatan rencana nutrisi.

8) Konsul ahli gizi/nutrisi pendukung tim untuk memberikan makanan yang mudah dicerna, secara nutrisi seimbang. Tujuannya : metode makan dan kebutuhan kalori didasarkan pada situasi/kebutuhan individu untuk memberikan nutrisi maksimal dengan upaya minimal pasien/ pengunaan enrgy.

9) Kaji pemeriksaan laboratorium. Tujuannya : mengevaluasi/mengatasi kekurangan dan mengawasi keefektifan terapi nutrisi.

10) Berikan oksigen tambahan selama makan sesuai indikasi. Tujuannya : menurunkan dispnea dan meningkatkan energy untuk makan dan meningkatkan masukan.
Pelaksanaan keperawatan

Pada tahap pelaksanaan tindakan pada kasus penelitian melaksanakan tindakan yang mengacu pada rencana perawatan yang telah dibuat sebelumnya serta menyesuaikannya dengan kondisi pasien pada saat diberikan. Dalam melaksanakan tindakan keperawatan, penulis bekerja sama dengan perawat ruangan dan berpartisipasi aktif dengan keluarga pasien.

Adapun tindakan keperawatan yang dilaksanakan sesuai dengan intervensi yang direncanakan antara lain:

Pasien I

1) Diagnosa II (gangguan pemenuhan kebutuhan nutrisi)

a) 11 Juli 2017 pada pukul 10.00 wib : mengkaji kebiasaan diet,masukan makanan saat ini,catat derajat kesulitan makan. Didapat hasil klien diberikan diet MB TKTP dan klien mengatakan tidak selera makan. Tindakan implementasi diatas sesuai dengan Doengoes (2012) menyatakan bahwa mengkaji kebiasaan diet dan masukan klien untuk mengetahui distress pernapasan klien sehingga membuat klien anoreksia.

b) 11 Juli 2017 pada pukul 10.10 wib : mengauskultasi bunyi usus. Didapat hasil bunyi usus terdengar 12 x.i, klien tampak kooperatif. Tindakan implemenetasi diatas sesuai dengan Doengoes (2012) menyatakan bahwa dengan mengauskultasi bunyi usus mengetahui adanya penurunan motilitas gaster yang berhubungan dengan pemasukan.

c) 11 Juli 2017 pada pukul 10.20 wib: memberikan perawatan oral sering,buang secret,berikan wadah khusus untuk sekali pakai dan tisu. Didapat hasil klien mau menggosok gigi dan membuang secret saat batuk. Tindakan implementasi diatas sesuai dengan Doengoes (2012) menyatakan bahwa dengan 
dilakukan nya perawatan oral dapat meningkatkan nafsu makan klien dan menghindari terjadinya mual.

d) 11 Juli 2017 pada pukul 10.30 wib: mendorong periode istirahat selama 1 jam sebelum dan sesudah makan. Didapat hasil klien melakukan istirahat sebelum dan sesudah makan. Tindakan implementasi diatas sesuai dengan Doengoes (2012) menyatakan bahwa istirahat sebelum dan sesudah makan Membantu menurunkan kelemahan selama waktu makan dam memberikan kesempatan untuk meningkatkan masukan kalori total.

e) 11 Juli 2017 pada pukul 10.35 wib : menghindari makanan penghasil gas dan minuman karbonat. Didapat hasil klien menghindari makanan penghasil gas dan minuman karbonat. Tindakan implementasi diatas sesuai dengan Doengoes (2012) menyatakan bahwa makanan bergas serta minuman berkarbonat Dapat menghasilkan distensi abdomen yang mengganggu nafas abdomen dan gerakan diafragma dan dapat meningkatkan dispnea.

f) 11 Juli 2017 pada pukul 10.40 wib: menghindari makanan yang sangat panas dan sangat dingin. Didapat hasil klien akan menghindari makanan yang sangat panas dan sangat dingin. Tindakan implementasi diatas sesuai dengan Doengoes (2012) menyatakan bahwa makanan yang sangat panas dan dingin dapat mencetuskan/meningkatkan spasme batuk.

g) 11 Juli 2017 pada pukul 10.50 wib : menimbang berat badan klien sesuai indikasi. Didapat hasil berat badan klien $55 \mathrm{~kg}$, klien menanyakan hasil penimbangannya. Tindakan implementasi diatas sesuai dengan Doengoes (2012) menyatakan bahwa penimbangan berat badan Berguna untuk mementukan kebutuhan kalori,menyusun tujuan berat badan,dan evaluasi keadekuatan rencana nutrisi. Menurut Kusyati (2018) menyatakan bahwa menimbang BB klien bertujuan untuk mengkaji BB klien dan perkembangannya, membantun menentukan program pengobatan, menentukan status nutrisi klien.

h) 11 Juli 2017 pada pukul 11.00 wib : berkolaborasi dengan ahli gizi/nutrisi pendukung tim untuk memberikan makanan yang mudah dicerna,secara nutrisi seimbang. Didapat hasil pemberian diet MB TKTP pada klien. Tindakan implementasi diatas sesuai dengan Doengoes (2012) menyatakan bahwa dengan kolaborasi dalam nutrisi klien Metode makan dan kebutuhan kalori didasarkan pada situasi/kebutuhan individu untuk memberikan nutrisi maksimal dengan upaya minimal pasien/pengunaan energy.

i) 11 Juli 2017 pada pukul 11.10 wib : memberikan oksigen tambahan selama makan sesuai indikasi . didapat hasil klien diberikan oksigen $2 \mathrm{~L} / \mathrm{i}$. Tindakan implementasi diatas sesuai dengan Doengoes (2012) menyatakan bahwa pemberian oksigen tambahan dapat Menurunkan dipsnea dan meningkatkan energy untuk makan meningkatkan masukan.

Pasien II

2) Diagnosa II (gangguan pemenuhan kebutuhan nutrisi)

a) 25 Juli 2017 pada pukul 08.00 wib : mengkaji kebiasaan diet,masukan makanan saat ini,catat derajat kesulitan makan. Didapat hasil klien diberikan diet M2 TKTP dan klien mengatakan tidak selera makan. 
Tindakan implementasi diatas sesuai dengan Doengoes (2012) menyatakan bahwa mengkaji kebiasaan diet dan masukan klien untuk mengetahui distress pernapasan klien sehingga membuat klien anoreksia.

b) 25 Juli 2017 pada pukul 08.05 wib : mengauskultasi bunyi usus. Didapat hasil bunyi usus terdengar 12 x.i, klien tampak kooperatif. Tindakan implemenetasi diatas sesuai dengan Doengoes (2012) menyatakan bahwa dengan mengauskultasi bunyi usus mengetahui adanya penurunan motilitas gaster yang berhubungan dengan pemasukan.

c) 25 Juli 2017 pada pukul 08.15 wib: memberikan perawatan oral sering,buang secret,berikan wadah khusus untuk sekali pakai dan tisu. Didapat hasil klien menggunakan tisu dan wadah untuk batuk. Tindakan implementasi diatas sesuai dengan Doengoes (2012) menyatakan bahwa dengan dilakukan nya perawatan oral dapat meningkatkan nafsu makan klien dan menghindari terjadinya mual.

d) 25 Juli 2017 pada pukul 08.30 wib: mendorong periode istirahat selama 1 jam sebelum dan sesudah makan. Didapat hasil klien melakukan istirahat sebelum dan sesudah makan. Tindakan implementasi diatas sesuai dengan Doengoes (2012) menyatakan bahwa istirahat sebelum dan sesudah makan Membantu menurunkan kelemahan selama waktu makan dam memberikan kesempatan untuk meningkatkan masukan kalori total.

e) 25 Juli 2017 pada pukul 08.40 wib : menghindari makanan penghasil gas dan minuman karbonat. Didapat hasil klien menghindari makanan penghasil gas dan minuman karbonat. Tindakan implementasi diatas sesuai dengan Doengoes (2012) menyatakan bahwa makanan bergas serta minuman berkarbonat Dapat menghasilkan distensi abdomen yang mengganggu nafas abdomen dan gerakan diafragma dan dapat meningkatkan dispnea. f) 25 Juli 2017 pada pukul 08.50 wib: menghindari makanan yang sangat panas dan sangat dingin. Didapat hasil klien akan menghindari makanan yang sangat panas dan sangat dingin. Tindakan implementasi diatas sesuai dengan Doengoes (2012) menyatakan bahwa makanan yang sangat panas dan dingin dapat mencetuskan/meningkatkan spasme batuk.

g) 25 Juli 2017 pada pukul 09.00 wib : menimbang berat badan klien sesuai indikasi. Didapat hasil berat badan klien $50 \mathrm{~kg}$, klien menanyakan hasil penimbangannya. Tindakan implementasi diatas sesuai dengan Doengoes (2012) menyatakan bahwa penimbangan berat badan Berguna untuk menentukan kebutuhan kalori,menyusun tujuan berat badan,dan evaluasi keadekuatan rencana nutrisi. Menurut Kusyati (2018) menyatakan bahwa menimbang BB klien bertujuan untuk mengkaji BB klien dan perkembangannya, membantun menentukan program pengobatan, menentukan status nutrisi klien.

h) 25 Juli 2017 pada pukul 09.15 wib : berkolaborasi dengan ahli gizi/nutrisi pendukung tim untuk memberikan makanan yang mudah dicerna,secara nutrisi seimbang. Didapat hasil pemberian diet M2 TKTP pada klien. Tindakan implementasi diatas sesuai dengan Doengoes (2012) menyatakan bahwa dengan kolaborasi dalam nutrisi klien Metode makan dan kebutuhan kalori didasarkan pada situasi/kebutuhan individu untuk memberikan nutrisi maksimal dengan upaya minimal pasien/pengunaan energy.

i) 25 Juli 2017 pada pukul 09.25 wib : memberikan oksigen tambahan selama makan sesuai indikasi. didapat hasil klien diberikan oksigen 5L/i. Tindakan implementasi diatas sesuai dengan Doengoes (2012) menyatakan bahwa pemberian oksigen tambahan dapat Menurunkan dipsnea dan 
meningkatkan energy untuk makan meningkatkan masukan.

\section{Evaluasi}

Hasil penelitian Rismawati (2014) menyatakan bahwa evaluasi keperawatan merupakan kegiatan dalam menilai tindakan keperawatan yang lebih ditentukan. Hal ini dilakukan dengan tujuan mengetahui pemenuhan kebutuhan klien secara optimal dan mengukur hasil proses keperawatan.

Setelah dilakukan tindakan terhadap pelaksanaan asuhan keperawatan pada pasien I dan II, maka tahap evaluasi semua masalah teratasi semua di hari ke tiga masing-masing klien. Selama delapan hari dilakukan perawatan terhadap pasien I (mulai dari tanggal 10 Juli sampai dengan 13 Juli 2017 dan pasien II mulai dari tanggal 25 Juli 2017 sampai dengan 28 Juli 2017). Kedua klien tersebut memiliki respon yang berbeda pada saat dilakukan tindakan keperawatan.

Berdasarkan tabel dari evaluasi diperoleh hasil yang berbeda antara kedua klien. Pada pasien I didapatkan evaluasi hari pertama pada tanggal 11 Juli 2017 pukul 10.00 wib pasien masih tidak selera makan, klien masih terasa sesak, terpasang nasal kanul 3L/i, BB klien $55 \mathrm{~kg}$, diet yang diberikan hanya dihabiskan $1 / 2$ porsi. Pada evaluasi kedua tanggal 12 Juli 2017 pukul 10.00 wib pasien masih belum selera makan, tetapi diet sudah habis 1 porsi, klien masih merasa sesak, terpasang nasal kanul 2L/i, BB klien $55 \mathrm{~kg}$. pada evaluasi ketiga tanggal 13 Juli 2018 pukul 10.00 wib pasien sudah nafsu makan, diet yang diberikan sudah habis 1 porsi, sesak nafas berkurang, klien tampak segar, BB klien $50 \mathrm{~kg}$. sehingga masalah pemenuhan kebutuhan nutrisi teratasi.

Pada pasien II diperoleh hasil evaluasi hari pertama pada tanggal 25 Juli 2017 pukul 08.00 wib pasien mengatakan tidak selera makan, nafsu makan menurun, diet yang diberikan hanya habis $1 / 4$ porsi, klien masih merasa sesak, terpasang nasal kanuk 5L/i, BB klien $50 \mathrm{~kg}$. pada evaluasi hari kedua tanggal 26 Juli 2017 klien masih belum nafsu makan, diet hanya habis $1 / 2$ porsi, klien masih merasa sesak, terpasang nasal kanul 5L/i, BB klien 50 kg. Pada evaluasi ketiga tanggal 27 Juli 2017 klien sudah nafsu makan, diet yang diberikan habis 1 porsi, klien tampak segar, sesak nafas mulai berkurang, masih terpasang nasal kanul 3L/i, BB klien $50 \mathrm{~kg}$. Sehingga masalah keperawatan pemenuhan nutrisi teratasi.

Evaluasi yang dilakukan disesuaikan dengan kondisi pasien dan fasilitas ada, sehingga rencana tindakan dapat dilaksanakan dengan SOAP meliputi subjektif, objektif, analisa, dan planning (Deden, 2012). Berdasarkan pembahasan tersebut diatas didapatkan dari kedua pasien mengalami peningkatan dalam pemenuhan nutrisi, meskipun proses peningkatan tersebut mengalami perbedaan waktu dari kedua pasien.

Perbedaan perkembangan kedua pasien dapat disebabkan karena perbedaan usia serta perbedaan keluhan yang dialami kedua pasien. Sehingga didapatkan perbedaan waktu dalam peningkatan pemenuhan nutrisi pada kedua pasien walaupun sama - sama masalah teratasi.

1. Pasien I (Tn.S) dengan masalah pemenuhan kebutuhan nutrisi teratasi setelah hari ketiga perawatan. Dikatakan teratasi karena dilihat dari pernyataan klien dan observasi dari perawat yaitu:

\section{Data Subjektif}

1) Klien mengatakan sudah selera makan

2) Klien melakukan istirahat sebelum dan sesudah makan

3) Klien mengatakan akan menghindari makanan yang sangat panas dan sangat dingin

4) Klien mengatakan sesak sudah berkurang Data Objektif:

1) Klien makan $3 x$ sehari diet yang diberikan MB TKTP, diet yang dimakan sudah habis 1 porsi

2) Bunyi usus terdengar normal $12 \mathrm{x} / \mathrm{i}$

3) Klien tampak kooperatif

4) Klien sudah selera makan

5) Klien tampak mengikuti anjuran perawat

6) Berat badan klien $55 \mathrm{~kg}$

7) Klien tampak menghindari makanan yang sangat panas dan sangat dingin

8) Klien memakai oksigen $2 \mathrm{~L} / \mathrm{i}$ Maka dari pernyataan klien dan observasi klien disimpulkan bahwa masalah pemenuhan kebutuhan nutrisi pada klien teratasi. 
2. Pasien II (Tn.L) dengan masalah pemenuhan kebutuhan nutrisi teratasi setelah hari ketiga perawatan. Dikatakan teratasi karena dilihat dari pernyataan klien dan observasi dari perawat yaitu:

Data Objektif:

1) Klien mengatakan sudah nafsu makan

2) Klien mengatakan menggunakan wadah dan tisu ketika batuk

3) Klien melakukan istirahat sebelum dan sesudah makan

Data Objektif:

1) Klien makan $3 \times$ sehari diet yang diberikan M2 TKTP

2) Bunyi usus $12 x / i$

3) Klien batuk menggunakan tisu dan wadah

4) Klien sudah nafsu makan

5) Klien tampak menghindari makanan yang sangat panas dan sangat dingin

6) BB klien $50 \mathrm{~kg}$

7) Terpasang oksigen $3 \mathrm{~L} / \mathrm{i}$

8) Klien sudah mampu menghabiskan porsi makanannya

Maka dari pernyataan klien dan observasi dari klien disimpulkan bahwa masalah gangguan pemenuhan nutrisi pada klien teratasi.

\section{Kesimpulan}

1. Pengkajian

Didapatkan hasil pengkajian dari kedua pasien memiliki beberapa kesamaan yaitu, penyebab dan tanda gejala. Adapun perbedaan antara kedua pasien meliputi umur yang berbeda, tanda - tanda vital yang berbeda, pemeriksaan laboratorium yang berbeda, serta pola pemenuhan nutrisi yang juga berbeda, dan terapi yang diberikan kepada pasien juga berbeda.

2. Diagnosa keperawatan

$$
\text { Berdasarkan dari diagnosa }
$$
keperawatan didapatkan hasil kedua pasien memiliki diagnosa keperawatan yang sama yaitu gangguan pemenuhan nutrisi yang ditandai dengan kehilangan nafsu makan pada pasien.

3. Rencana tindakan keperawatan

Hasil dari rencana tindakan keperawatan yang telah dilakukan yaitu kedua pasien memiliki rencana tindakan yang sama sesuai dengan SOP rencana tindakan yang ada di rumah sakit meliputi kaji kebiasaan diet, auskultasi bunyi usus, perawatan oral, pemberian periode istirahat, menghindari makanan bergas dan berkarbonat, menghindari makanan yang sangat panas dan sangat dingin, penimbangan berat badan, konsul dengan ahli gizi dalam pemberian makanan, serta pemberian oksigen selama makan.

4. Tindakan keperawatan

Tindakan keperawatan yang dilakukan kepada kedua pasien sama, sesuai dengan rencana tindakan keperawatan misalnya dengan pemberian diet yang sama yaitu MB TKTP. Adapun hal yang membedakan yaitu terapi yang didapatkan kedua pasien tidak sama.

5. Evaluasi

Pada hasil evaluasi antara kedua pasien didapatkan hasil yang berbeda. Pada pasien I sudah nafsu makan pada hari ke 2, diet yang diberikan sudah habis 1 porsi, sesak mulai berkurang dan pemberian nasal kanul 2L/i. dan pada hari ke 3 klien tampak lebih segar. Sedangkan pada pasien II keluhan masih belum nafsu makan, diet hanya habis $1 / 4$ porsi sesak masih ada, dan belum ada peningkatan berat badan. Dan pada hari ke 3 perawatan nafsu makan klien sudah ada, diet yang diberikan sudah mampu di habis kan 1 porsi, keluhan sesak mulai berkurang, klien tampak lebih segar dan pemberian nasal kanul 3L/i. Sehingga kedua pasien mengalami peningkatan dalam pemenuhan nutrisi meskipun dalam proses peningkatan tersebut mengalami perbedaan waktu dan tingkat kemampuan.

\section{Daftar Pustaka}

Astuti, W. 2011. Ilmu gizi dalam keperawatan, Jakarta, TIM.

Dani 2012. Karateristik penderita penyakit PPOK di Rumah Sakit Immanuel, Bandung.

Dinarti. 2013. Dokumentasi keperawatan, Jakarta, TIM.

Doengoes, E.M. 2012. Rencana keperawatan, Jakarta, Buku Kedokteran, EGC.

Fajrin, O. 2015. Gambaran fungsi paru pada pasien Penyakit Paru Obstruktif Kronik. Jurnal Fakultas Keperawatan Volume No. 2 , Jakarta.

Ghofar,A. 2014. Hubungan perilaku merokok dengan kejadian PPOK di Ruang 
Cempaka Rumah Sakit Umum, Padila. 2012. Keperawatan medikal bedah, Jombang. $\quad$ Jakarta.

Hidayat, A. 2012. Kebutuhan dasar manusia I, Riskesdas. 2013. Riset Kesehatan Dasar Jakarta, Salemba Medika.

Manurung, S. 2013. Gangguan system pernafasan akibat infeksi, Jakarta, TIM.

Mutaqin, A. 2013. Asuhan keperawatan pada klien dengan system pernapasan, Jakarta, Salemba Medika.

Nainggolan, H. 2012. Analisis diet tinggi kalori tinggi protein pada pasien PPOK, Jakarta.

Nieniek. 2012. Peningkatan fungsi ventilasi paru pada penyakit PPOK dengan posisi high folwer dan orthopneic, Bandung.

Nugroho, Y.A. 2011. Batuk efektif dalam pengeluaran dahak pada pasien dengan ketidakefektifan bersihan jalan nafas di Instalasi Rehabilitasi Medik Rumah Sakit Baptis Kediri. Jurnal STIKES RS Baptis Kediri. Tahun 2013, Kementrian Kesehatan. Republik Indonesia, di akses pada tanggal 14 maret 2014 (http:www.depkes.go.id).

Smeltzer. 2014. Keperawatan medical bedah, Jakarta. Penerbit Buku Kedokteran, EGC.

Suryadinata. 2017. Perbedaan asupan nutrisi makanan dan IMT perokok aktif dengan non-perokok, Jakarta.

Tabrani, R. 2013. Penyakit paru fleura, Jakarta.

Zamzam. 2012. Epidemiologi pasien dengan penyakit PPOK, Amerika. 